\title{
PENGARUH LAMA SIMPAN PADA VIGOR BENIH DAN KECAMBAH SORGUM (Sorghum bicolor [L.] Moench) GENOTIPE KAWALI DAN P/F-10-90A
}

\author{
SEED STORAGE TIME EFFECT ON SEED VIGOR AND SPROUTS \\ OF SORGHUM ( Sorghum bicolor [L.] Moench) GENOTYPE KAWALI \\ AND P/F-10-90A
}

\author{
Iska Hartina Anggraini*, Muhammad Kamal, Eko Pramono dan Kukuh Setiawan \\ Jurusan Agroteknologi, Fakultas Pertanian, Universitas Lampung, \\ Jln.Prof. Soemantri Brodjonegoro No.1, Bandar Lampung 35145 \\ *Email: iskahartinaanggraini@gmail.com
}

\begin{abstract}
Sorghum is a type of carbohydrate-producing serelia plant. Sorghum has a great potential to be developed in Indonesia. Seed storing time is the time period of the seed storage before the seed is planted again, while the storage of the seed is carried out with the aim of maintaining seed viability in the save period for as long as possible and can be used for the next planting period. The purpose of this study was to determine the effect of storage time on seed vigor and sprouts of Kawali and P/F-10-90A genotypes. This research was conducted at the Laboratory of Seed and Plant Breeding, Faculty of Agriculture, University of Lampung, Bandar Lampung which runs from February 2017 until February 2018. This study uses split plot design with 3 group replications. The main plot is the storage time $(L S)$ that was consisted of $0,4,8$ and 12 months storage time period. Subplot is genotype (G), which consists of Kawali (G1) and $P / F-10-90 A$ (G2). The results showed that seed vigor and sprouts decreased significantly at 4 and 8 months storage time with the percentage of dead seeds $16.7 \%$ and $40.7 \%$, while the percentage of normal strong sprouts at 4 months amounted to $74 \%$ for genotype $P / F-10-90 \mathrm{~A}$ and 8 months $54 \%$ for genotype Kawali. P/F-10-90A genotypes have higher seed vigor and sprouts vigor compared to Kawali genotypes as indicated by dead seed variables, strong normal sprouts, normal sprout length canopy, long root primary roots, normal sprouts, dry weight normal sprouts, and normally strong sprouts. The effect of interaction between storage time and genotype was shown by seed vigor of genotype P/F-10-90-A seedlings which were proven to be superior for 4, 8 and 12-month storage time period. Excellence of genotype P/ F-10-90-A make it can be stored and was allowed to be used as good seed on next season farming.
\end{abstract}

Keywords: Sorghum, genotype, storage time, vigor, sprouts.

\begin{abstract}
ABSTRAK
Sorgum merupakan salah satu jenis tanaman serelia penghasil karbohidrat. Sorgum mempunyai potensi besar untuk dikembangkan di Indonesia. Lama simpan adalah waktu penyimpanan benih sebelum benih tersebut ditanam kembali, sedangkan Penyimpanan benih dilakukan dengan tujuan untuk mempertahankan viabilitas benih dalam periode simpan yang sepanjang mungkin dan dapat digunakan untuk periode tanam selanjutnya. Tujuan penelitian ini adalah mengetahui pengaruh lama simpan pada vigor benih dan kecambah sorgum genotipe Kawali
\end{abstract}


dan P/F-10-90A. Penelitian ini dilaksanakan di Laboratorium Benih dan Pemuliaan Tanaman, Fakultas Pertanian, Universitas Lampung, Bandar Lampung yang berlangsung dari bulan Februari 2017 sampai dengan Februari 2018. Penelitian ini menggunakan rancangan petak terbagi (Split Plot) dengan 3 kelompok sebagai ulangan. Petak utama berupa lama simpan (LS) yang terdiri dari lama simpan 0, 4, 8 dan 12 bulan. Anak petak adalah genotipe (G), yang terdiri dari Kawali (G1) dan P/F-10-90A(G2). Hasil penelitian menunjukkan bahwa Vigor benih dan kecambah menurun secara signifikan pada lama simpan 4 dan 8 bulan dengan persentase benih mati $16,7 \%$ dan sebesar $40,7 \%$, sedangkan pada persentase kecambah normal kuat pada 4 bulan sebesar $74 \%$ dan 8 bulan 54\% genotipe P/F-10-90A dan Kawali. Genotipe P/F-10-90A mempunyai vigor benih dan vigor kecambah yang lebih tinggi dibandingkan dengan genotipe Kawali yang ditunjukkan oleh variabel benih mati, kecambah normal kuat, panjang tajuk kecambah normal, panjang akar primer kecambah normal, bobot kering kecambah normal, dan kecambah normal kuat. Pengaruh interaksi lama simpan dan genotipe nyata, ditunjukkan oleh vigor benih dan kecambah P/F-10-90-A yang terbukti unggul untuk lama simpan 4, 8 dan 12 bulan. Keunggulan genotipe P/F-10-90-A tersebut memungkinkan dapat disimpan dan digunakan untuk musim pertanamaan berikutnya.

Kata Kunci : Benih sorgum, genotipe, lama simpan, vigor benih, vigor kecambah.

\section{PENDAHULUAN}

Sorgum ( Sorghum bicolor L. ) merupakan salah satu jenis tanaman serelia penghasil karbohidrat. Sorgum mempunyai potensi besar untuk dikembangkan di Indonesia. Menurut Susilowati dan Saliem (2013), sorgum mempunyai kelebihan berupa memiliki biji dan biomasa tinggi, adaptasi sorgum yang luas sehingga dapat ditanam di hampir semua lahan, toleran terhadap kekeringan, salinitas tinggi dan genangan air, memerlukan lebih sedikit pupuk, mudah dalam budidaya dan dapat diratoon. Penyediaan benih bermutu merupakan upaya untuk mendukung diversifikasi pangan. Kebutuhan benih pada setiap saat musim tanam di tingkat petani menjadi faktor pembatas dalam berproduksi. Jika petani menggunakan benih bermutu rendah maka hasil produksi juga rendah sehingga upaya penyedian pangan alternatif tidak tercapai.

Kendala yang dihadapi di lapangan pada tanaman sorgum yaitu langkanya ketersedian benih sorgum dengan mutu yang baik. Lama simpan benih sorgum masih menjadi salah satu faktor yang mempengaruhi ketersedian benih bermutu tersebut. Oleh karena itu penentuan lama simpan benih sorgum untuk mendapatkan benih dengan mutu baik dari tanaman sorgum masih menjadi masalah. Menurut Yuniarti et al (2012) bahwa terjadi perubahan fisiologis pada benih eboni selama penyimpanan yang mengakibatkan adanya penurunan nilai kecambah benih.

Penyimpanan benih adalah upaya-upaya yang dilakukan untuk mempertahankan viabilitas benih dalam periode simpan tertentu. Masalah yang terjadi selama penyimpanan benih yaitu kemunduran benih yang terus terjadi dan tidak dapat dihentikan hanya dapat diperlambat. Kemunduran benih merupakan proses penurunan mutu fisiologis benih yang menyebabkan perubahan menyeluruh di dalam benih. Benih yang 
mengalami proses kemunduran akan menyebabkan perubahan menyeluruh dalam benih baik secara fisik, fisiologis, maupun biokimia yang mengakibatkan menurunnya viabilitas benih.

Fikri (2015) menyatakan bahwa penggunaan genotipe yang mempunyai komposisi genetik terbaik dan pengaturan kadar air benih saat penyimpanan dilakukan untuk menekan laju kemunduran benih dan menjaga vigor benih. Vigor benih adalah jumlah total sifat-sifat benih menciptakan tegakan yang memuaskan pada kondisi lapangan yang tidak menguntungkan. Benih yang bervigor akan cepat berkecambah dan merata, tahan simpan, bebas dari penyakit benih, tahan terhadap berbagai gangguan mikroorganisme, dan bibit tumbuh kuat baik ditanah basah maupun kering. (Heydecker,1980). Benih yang performanya bagus disebut benih bervigor tinggi sedangkan sebaliknya adalah benih bervigor rendah. Penurunan vigor dan mutu fisik benih pada periode simpan tertentu berbedabeda tergantung dari varietas benih tersebut. Penelitian pengaruh lama simpan simpan dan genotipe yang berbeda dengan tujuan untuk mengkaji dan mengetaui: (1) Mengetahui Pada lama simpan berapa vigor kecambah menurun secara signifikan pada periode simpan 0,4,8,12 bulan sorgum genotipe Kawali dan P/F-10-90A (2) Mengetahui pengaruh perbedaan dua genotipe sorgum pada vigor kecambah benih sorgum, (3) Mengetahui perbedaan vigor kecambah dalam penyimpanan yang dipengaruhi oleh perbedaan genotipe.

\section{BAHAN DAN METODE}

Penelitian dilaksanakan di Laboratorium Benih dan Pemuliaan Tanaman Fakultas Pertanian, Universitas Lampung pada bulan Februari 2017 sampai dengan Februari 2018. Alat-alat yang digunakan pada penelitian ini adalah pendingin udara (AC), seed counter tipe Seedburo 801, alat pembagi tepat, conductivity meter tipe Cyber scan con 11, alat pengukur kadar air tipe GMK, tampah plastik, gelas mineral, alat pengempa kertas, germinator tipe IPB 73 2A/2B, sprayer, klip kertas, amplop kertas, plastik klip, nampan, dan alat tulis. Bahan-bahan yang digunakan pada penelitian ini adalah benih sorgum genotipeP/F10-90A, Kawali, aquades, kertas merang, air, dan plastik. Penelitian ini menggunakan rancangan percobaan Rancangan Split Plot dengan 3 kelompok sebagai ulangan. Petak utama berupa lama simpan berupa ) bulan (L1), 4 bulan (L2), 8 bulan (L3), dan 12 bulan (L4). Anak petak berupa genotipe (G), yang terdiri dari Kawali (G1) dan P/F-10-90A (G2). Dengan demikian terdapat 8 kombinasi perlakuan dan terdapat 24 satuan percobaan.

Pemanenan dan persiapan benih dimulai dari bulan Januari 2017. Benih sorgum berasal dari pertanaman di Desa TulungAgung, Kecamatan Gading Rejo, Kabupaten Pringsewu. Genotipe benih yang digunakan adalah Kawali dan P/F-10-90A. Benih sorgum yang telah dirontokkan dimasukkan kedalam wadah amplop kertas yang kemudian dimasukan kedalam oven tipe memmert. Pengeringan dilakukan dengan suhu $40^{\circ} \mathrm{C}$ selama 32 jam agar embrio pada benih tidak mati. Pengeringan dilakukan sampai kadar 
air turun menjadi $\pm 8 \%$.

Benih sorgum yang sudah mencapai kadar air sebesar $\pm 8 \%$ selanjutnya didinginkan pada desikator. Benih dikemas ke dalam plastik klip dengan jumlah 130 butir/plastik kemudian udara di dalam plastik dikeluarkan lalu direkatkan penutup plastik. Setelah itu, masing-masing plastik sampel diberi label sesuai dengan perlakuan, penggunaan wadah ini bertujuan untuk menjaga agar kadar air stabil dan tidak meningkat ketika dilakukan penyimpanan diruang simpan.

Benih yang sudah dikemas ke dalam plastik klip disimpan dengan menempatkan kantung benih pada nampan dengan dibagi kedalam 3 blok, kemudian nampan ditutup dan disimpan pada suhu ruang $26 \pm 1,08^{\circ} \mathrm{C}$. Pengukuran vigor benih dan kecambah diakukan dengan uji perkecambahan benih. Uji perkecambahan benih dilakukan menggunakan metode UKD (Uji Kertas Digulung ) (ISTA, 2009). Uji perkecambahan dilakukan dengan kertas CD/ kertas buram. Benih sebanyak 25 butir diletakkan diatas 2 kertas $\mathrm{CD} /$ kertas buram lalu ditutup menggunakan 2 lembar kertas tersebut. Kertas CD dilapisi oleh plastik agar kertas tidak sobek ketika digulung dalam UKDdp, kemudian dimasukkan dengan posisi didirikan tegak di dalam Germinator tipe IPB 73-2A/B bersuhu $28,17^{\circ} \mathrm{C} \pm 1,79 \mathrm{Sd}$. Pengamatan dilakukan pada hari ke empat setelah pengecambahan sampai hari ke lima. Pengamatan dari metode ini adalah kecambah normal kuat (KNK), panjang taku kecambah normal (PTKN), panjang akar kecambah normal (PAPKN), bobot kering kecambah normal (BKKN), Benih mati (BM), kecambah normal total (KNT).

\section{HASIL DAN PEMBAHASAN}

Hasil penelitian menunjukan bahwa terdapat interaksi antara lama simpan dengan genotipe pada variabel benih mati dan kecambah normal kuat dan kecambah normal total

Hasil penelitian menunjukan bahwa semakin lama benih disimpan maka menyebabkan kemunduran benih. Pada variabel benih mati, kadar air, kecambah normal total semakin menurun setelah disimpan menjadi indikator kemunduran benih. Penurunan persentase kecambah normal total dibarengi oleh penurunan benih mati yang dihasilkan. Pengaruh lama simpan ditunjukan pada variabel kecambah normal total rata-rata presentase kecambah tertinggi pada lama simpan 0 bulan sebesar $93,7 \%$ hasil pada lama simpan 4 bulan persentase kecambah normal total menurun sebesar $74 \%, 8$ bulan sebesar 54\% dan pada lama simpan 12 bulan penurunan tidak signifikan sebesar 50\% begitupula dengan variabel benih mati yang dihasilkan bahwa semakin lama penyimpanan persentase benih mati semakin meningkat. Hal tersebut sejalan dengan penelitian Azadi dan Younesi, (2013) menunjukkan bahwa persentase perkecambahan, indeks perkecambahan menurun secara signifikan dengan penyimpanan. Benih yang didimpan pada 8 bulan memiliki vigor benih dan kecambah lebih baik dengan penyimpanan 12 bulan.

Penurunan cadangan makanan pada benih terjadi karena benih mengalamai proses metabilsme yaitu respirasi sehingga menghasilkan air dan $\mathrm{CO} 2$ yang menyebabkan cadangan makanan benih berkurang. Hal ini sejalan dengan pernyataan Tuwu et al. (2012) 
Tabel 1. Rangkuman hasil analisis ragam pengaruh lama simpan pada vigor benih dan kecambah sorgum (Sorghum bicolor [L]. Moench.) genotpe Kawali dan P/F-10-90A

\begin{tabular}{|c|c|c|c|c|}
\hline \multirow{2}{*}{ No } & \multirow{2}{*}{ Variabel } & \multicolumn{3}{|c|}{ Pengaruh Perlakuan } \\
\hline & & $\mathrm{L}$ & G & $\mathrm{LXG}$ \\
\hline 1 & Kecambah Normal Kuat (\%) & ** & $* *$ & $* *$ \\
\hline 2 & Kecambah Normal Total (\%) & $* *$ & ** & ** \\
\hline 3 & Benih Mati (\%) & $* *$ & $* *$ & ** \\
\hline 4 & Bobot Kering Kecambah Normal (mg) & $* *$ & $* *$ & tn \\
\hline 5 & Panjang Tajuk Kecambah Normal (cm) & $* *$ & $* *$ & tn \\
\hline 6 & Panjang Akar Kecambah Normal (cm) & $* *$ & $* *$ & tn \\
\hline 7 & Kecambah Normal Kuat (\%)Kadar air (\%) & $* *$ & $* *$ & tn \\
\hline
\end{tabular}

Keterangan: L : Lama Simpan; G: Genotipe; L x G: Interaksi Lama Simpan dengan Genotipe; **: Berbeda nyata pada $\alpha=$ 0,05 ; tn: Tidak berbeda nyata pada $\alpha=0,05$.

Tabel 2. Pengaruh lama simpan terhadap vigor benih dan kecambah sorgum ( Sorgum bicolor [L.] Moench) genotipe Kawali dan P/F-10-90A

\begin{tabular}{|c|c|c|c|c|c|}
\hline \multirow{2}{*}{ Variabel } & \multicolumn{4}{|c|}{ Lama simpan } & \multirow{2}{*}{ BNJ $5 \%$} \\
\hline & $\mathrm{L} 1$ & $\mathrm{~L} 2$ & L3 & L4 & \\
\hline Kecambah Normal Kuat (\%) & $93,70 \mathrm{a}$ & $74,00 \mathrm{~b}$ & $56,00 \mathrm{c}$ & $50,00 \mathrm{c}$ & 10,98 \\
\hline Kecambah Normal Total (\%) & $96,00 \mathrm{a}$ & $76,67 \mathrm{~b}$ & $56,00 \mathrm{c}$ & $54,67 \mathrm{c}$ & 9,22 \\
\hline Benih Mati $(\%)$ & $5,00 \mathrm{a}$ & $16,70 \mathrm{a}$ & $40,70 \mathrm{~b}$ & $45,30 \mathrm{~b}$ & 13,9 \\
\hline Bobot Kering Kecambah Normal (mg) & $46,60 \mathrm{a}$ & $40,03 \mathrm{ab}$ & $31,50 \mathrm{~b}$ & $21,30 \mathrm{c}$ & 8,04 \\
\hline Panjang Tajuk Kecambah Normal (cm) & $8,20 \mathrm{bc}$ & $12,60 \mathrm{a}$ & $11,50 \mathrm{ab}$ & $6,80 \mathrm{c}$ & 3,52 \\
\hline Kadar Air $(\%)$ & $8,10 \mathrm{a}$ & $8,80 \mathrm{~b}$ & $8,90 \mathrm{~b}$ & $10,00 \mathrm{c}$ & 0,52 \\
\hline Panjang Akar Primer Kecambah Normal $(\mathrm{cm})$ & $9,30 \mathrm{bc}$ & $11,80 \mathrm{a}$ & $10,00 \mathrm{~b}$ & $8,20 \mathrm{c}$ & 1,75 \\
\hline
\end{tabular}

Keterangan : Angka-angka yang diikuti huruf yang sama tidak berbeda nyata menurut uji BNJ 5\%

bahwa vigor benih mengalami penurunan atau kemunduran kronologis setelah melewati periode simpan tertentu. Hasil penelitian Azadi dan Younesi (2013), menyetakan bahwa persentase perkecambahan, indeks perkecambahan, persentase bibit normal tertinggi terdapat pada benih sorgum 0 hari penyimpanan.

Hasil penelitian menunjukkan bahwa perbedaan genotipe menyebabkan perbedaan vigor benih dan kecambah dikarenakan faktor genetiknya. Setelah disimpan, perbedaan genetik mempengarui mutu benih yang ditunjukkan oleh variabel benih mati, kecambah normal kuat, panjang tajuk kecambah normal, panjang akar primer kecambah normal dan bobot kering kecambah normal. Hal ini sejalan dengan penelitian Moyo et al., (2015) yang menyatakan bahwa genotipe sorgum yang dievaluasi merespon secara berbeda untuk semua metode uji kekuatan dan uji perkecambahan karena benih secar genetis tampil beda saat terkena kondisi yang tidak sesuai. Hasil penelitian Mangoendidjojo (2008) mendukung pernyataan tersebut bahwa perbedaan genotipe akan menyebabkan perbedaan bentuk dan sifat biji sehingga akan mempengaruhi mutu benih setelah penyimpanan. 
Hasil penelitian menunjukkan bahwa genotipe $\mathrm{P} / \mathrm{F}-10-90 \mathrm{~A}$ secara metabolisme mempunyai vigor lebih baik dibandingkan dengan genotipe Kawali. Hasil penelitian Nisa (2015), mengemukakan bahwa semakin tinggi nilai persentase kecambah normal maka semakin tinggi nilai bobot kering brangkasan, hal ini sejalan dengan hasil penelitian bahwa persentase kecambah normal yang tinggi diikuti dengan nilai bobot kering kecambah normal dan pesentase benih mati. Benih yang memiliki vigor yang baik dapat dilihat dari nilai bobot kering kecambahnya. Kecambah dengan berat kering tertinggi akan memiliki vigor yang tinggi karena mengandung cadangan makanan yang lebih besar. Hal ini sejaln dengan hasil penelitian bahwa persentase kecambah normal tinggi diikuti dengan nilai bobot kering kecambah normal dan persentase benih mati. Persentase kecambah normal total P/F-10-90A $88,67 \%$ sedangkan persentase kecambah normal total Kawali sebesar 53\% dan nilai bobot kering kecambah normal P/F-10-90A lebih tinggi (38,78 mg) dari pada Kawali (30,92 mg).

Tabel 3. Pengaruh Genotipe terhadap Vigor Benih dan Kecambah Sorgum ( Sorgum bicolor [L.] Moench) Genotipe Kawali dan P/F-10-90A

\begin{tabular}{lrrr}
\hline \multicolumn{1}{c}{ Variabel } & \multicolumn{2}{c}{ Genotipe } & \multirow{2}{*}{ BNJ 5\% } \\
\cline { 2 - 3 } & G1 & G2 & 6,63 \\
Kecambah Normal Kuat (\%) & $49 \mathrm{~b}$ & $86,8 \mathrm{a}$ & 5,58 \\
Kecambah Normal Total (\%) & $53 \mathrm{~b}$ & $88,67 \mathrm{a}$ & 5,66 \\
Benih Mati (\%) & $44 \mathrm{~b}$ & $9,8 \mathrm{a}$ & 3,74 \\
Bobot Kering Kecambah Nrmal (mg) & $30,92 \mathrm{~b}$ & $38,78 \mathrm{a}$ & 1,22 \\
Panjang Tajuk Kecambah Normal (cm) & $7,8 \mathrm{~b}$ & $11,8 \mathrm{a}$ & 0,86 \\
Panjang Akar primer Kecambah Normal n (cm) & $9,1 \mathrm{~b}$ & $10,6 \mathrm{a}$ & 0,16 \\
Kadar Air (\%) & $8,8 \mathrm{a}$ & $9 \mathrm{a}$ & \\
\hline
\end{tabular}

Keterangan : Angka-angka yang diikuti huruf yang sama tidak berbeda nyata menurut uji BNJ 5\%

Tabel 4. Pengaruh interaksi lama simpan dan genotipe pada variabel kecambah normal kuat (\%)

\begin{tabular}{ccc}
\hline \multirow{2}{*}{ Lama simpan (bulan) } & \multicolumn{2}{c}{ Genotipe } \\
\cline { 2 - 3 } 0 & Kawali & P/F-10-90A \\
\hline 4 & $92,00^{\mathrm{a}}$ & $95,33^{\mathrm{a}}$ \\
& $\mathrm{A}$ & $\mathrm{A}$ \\
8 & $53,33^{\mathrm{b}}$ & $94,67^{\mathrm{a}}$ \\
& $\mathrm{B}$ & $\mathrm{A}$ \\
12 & $32,00^{\mathrm{c}}$ & $80,00^{\mathrm{b}}$ \\
& $\mathrm{B}$ & $\mathrm{A}$ \\
BNJ $\alpha 0,05$ & $18,67^{\mathrm{d}}$ & $81,33^{\mathrm{bc}}$ \\
& $\mathrm{B}$ & $\mathrm{A}$ \\
\hline
\end{tabular}

Keterangan: Dua nilai tengah diikuti huruf yang sama menurut uji BNJ pada $\alpha 5 \%$, huruf kapital untuk bari dan huruf kecil untuk kolom. 
Tabel 5. Pengaruh interaksi lama simpan dan genotipe pada variabel benih mati (\%)

\begin{tabular}{ccc}
\hline Lama simpan (bulan) & \multicolumn{3}{c}{ Genotipe } \\
\cline { 2 - 3 } 0 & Kawali & P/F-10-90A \\
\hline & $14,79^{\mathrm{a}}$ & $8,57^{\mathrm{a}}$ \\
& $\mathrm{B}$ & $\mathrm{A}$ \\
8 & $31,85^{\mathrm{b}}$ & $9,32^{\mathrm{ab}}$ \\
& $\mathrm{B}$ & $\mathrm{A}$ \\
12 & $54,75^{\mathrm{c}}$ & $21,47^{\mathrm{c}}$ \\
& $\mathrm{B}$ & $\mathrm{A}$ \\
& $58,90^{\mathrm{c}}$ & $24,46^{\mathrm{cd}}$ \\
BNJ $\alpha 0,05$ & $\mathrm{~B}$ & $\mathrm{~A}$ \\
\hline
\end{tabular}

Keterangan: Dua nilai tengah diikuti huruf yang sama menurut uji BNJ pada $\alpha 5 \%$, huruf kapital untuk bari dan huruf kecil untuk kolom.

Tabel 6. Pengaruh interaksi lama simpan dan genotipe pada variabel kecambah normal total (\%)

\begin{tabular}{ccc}
\hline \multirow{2}{*}{ Lama simpan (bulan) } & \multicolumn{2}{c}{ Genotipe } \\
\cline { 2 - 3 } & Kawali & P/F-10-90A \\
\hline & $94,67^{\mathrm{a}}$ & $97,33^{\mathrm{a}}$ \\
4 & $\mathrm{~A}$ & $\mathrm{~A}$ \\
& $58,67^{\mathrm{b}}$ & $94,67^{\mathrm{a}}$ \\
& $\mathrm{B}$ & $\mathrm{A}$ \\
& $32,00^{\mathrm{c}}$ & $82,67^{\mathrm{b}}$ \\
& $\mathrm{B}$ & $\mathrm{A}$ \\
& $26,67^{\mathrm{cd}}$ & $80,00^{\mathrm{bc}}$ \\
& $\mathrm{B}$ & $\mathrm{A}$ \\
\hline
\end{tabular}

Keterangan: Dua nilai tengah diikuti huruf yang sama menurut uji BNJ pada $\alpha 5 \%$, huruf kapital untuk bari dan huruf kecil untuk kolom.

Menurut Balai Penelitian Tanaman serealia (2018) bahwa, warna sorgum merah disebabkan oleh adanya testa atau lapisan sel tipis dibawah pericarp yang mengandung unsur tanin, ketebalan lapisan pericarp menentukan warna biji dimana semakin tebal lapisan pericarp semakin banyak variasi warna, sorgum merah mempunyai komposisi karbohidrat 73,92\%, protein $9,02 \%$, lemak $3,80 \%$, tanin 10,60\% serta air sebesar 9,90\%, lebih tinggi dari pada varietas Kawali yang memiliki kandungan karbohidrat 87,87\%, lemak $1,97 \%$, protein $8,81 \%$. Karena kandungan tanin yang tinggi serta cadangan makanan yang tinggi pada sorgum merah menyebabkan proses respirasi berjalan lambat sehingga laju deteriosasi rendah sehingga genotipe P/F-10-90A memiliki vigor kecambah yang lebih tinggi dibandingkan dengan Kawali. Sadjad, dkk (1994), menyatakan kemampuan berkecambah suatu benih berhubugan dengan cadangan makanan benih. 


\section{KESIMPULAN}

Hasil penelitian disimpulkan bahwa vigor benih dan kecambah menurun secara signifikan pada lama simpan 4 dan 8 bulan dengan persentase benih mati $16,7 \%$ dan sebesar $40,7 \%$, sedangkan pada persentase kecambah normal kuat pada 4 bulan sebesar $74 \%$ dan 8 bulan 54\% genotipe P/F-10-90A dan Kawali. Genotipe P/F-10-90A mempunyai vigor benih dan vigor kecambah yang lebih tinggi dibandingkan dengan genotipe Kawali yang ditunjukkan oleh variabel benih mati, kecambah normal kuat, panjang tajuk kecambah normal, panjang akar primer kecambah normal, bobot kering kecambah normal, dan kecambah normal kuat. Pengaruh interaksi lama simpan dan genotipe nyata, ditunjukkan oleh vigor benih dan kecambah P/F-10-90-A yang terbukti unggul untuk lama simpan 4 bulan.

\section{DAFTAR PUSTAKA}

Azadi M.S., dan younesi E . 2013. The Effects of Storage on Germination Characteristic and Enzyme Activity of Sorghum Seeds. Journal of Stress Physiology \& Biochemistry. 289$298 \mathrm{hlm}$.

Balai Penelitian Tanaman Serealia. 3013. http:// balitsereal.litbang.pertanian.go.id//index.php/ profil-126/sorgum/511-varietas-kawalisorgum. Diakses pada 1 Desember 2017 pukul 23.00 WIB.

Heydecker. 1997. Accelerated Germination By Osmmotic Seed Treatment. Nature 246;4246G.
ISTA. 2009. International Rules for Seed Testing. Third Edition. International Rules for Seed Testing Association. Zurich.

Mangoendidjojo, W. 2008. Dasar-Dasar Pemuliaan Tanaman. Kanisius. Yogyakarta. $182 \mathrm{hlm}$

Nisa, N.R. 2015. Pengaruh dosis pupuk susulan saat pengisian polong (R3) pada viabilitas benih kedelai (Glycine max (L) Merr) varietas dering -1 pasca simpan 5 bulan. Skripsi. Universitas Lampung.

Nurisma, I. 2014. Pengaruh jemis kemasan dan suhu ruang simpan terhadap viabilitas benih sorgum (Sorghum bicolor [L.] Moench). Jurnal Penelitian Pertanian Terapan. 15(3): 183190.

Moyo, R., E. Ndlovu, N. Moyo, M. Maphosa. 2015. Physiological parameters of seed vigour in ex situ stored sorghum germplasm. J. Cereals oilseeds.(6) 6:31-38.

Sadjad, S. 1994. Dari Benih Kepada Benih. Gramedia Widiasarana. Jakarta. $144 \mathrm{hlm}$.

Susilowati, S. Hdan H. P. Saliem, 2013. Perdagangan sorgum di Pasar Dunia dan Asia Serta Prospek pengembangannya di Indonesia. IAARD Pr3ess Badan Penelitian dan Pengembangan Pertanian. 17-34 hlm.

Sutopo, L. 2004. Teknologi Benih. Edisi Revisi. Raja Grafindo Persada. Jakarta.223 hlm.

Tuwu, E. R., G. A. K. Sutariati, dan Suaib. 2012. Pengaruh KadarAir Benih dan Jenis Kemasan Terhadap Vigor Benih Sorgum (Sorghum bicolor [L.] Moench.)dalam Enam Bulan Masa Simpan. Jurnal Berkala Penilitian Agronomi 1(2): 184-193. 
Yuniarti,N., Dharmawati F. Djaman. 2015. Teknik

Pengemasan Yang Tepat Untuk

Mempertahankan Viabilitas Benih Bakau

(Rhizophora Apiculata) Selama

Penyimpanan. Prosiding Seminar Nasional

Masyarakat Biodiversitas Indonesia. Balai

Penelitian Teknologi Perbenihan Tanaman

Hutan Jawa Barat. . Hlm 1438-144. 